\title{
Classification of the Asian non-marine Cretaceous System
}

\author{
GUO FUXIANG
}

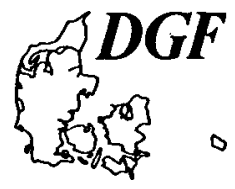

\begin{abstract}
Guo Fuxiang: Classification of the Asian non-marine Cretaceous System. Bull. geol. Soc., Denmark, vol. 33, pp. 115-122, Copenhagen, September, 11th, 1984. https://doi.org/10.37570/bgsd-1984-33-09

The Asian non-marine Cretaceous System may be divided into two geographical provinces: a southern one, dominated by clastic red salt-bearing formations, and a northern one, dominated by clastic grey, yellowish green and black formations containing coal (kukersit). Vertically, on the basis of three trigonioidacean assemblages (bivalves), the System may be subdivided into Lower, Middle and Upper Cretaceous, three provincial series exhibiting this tripartite character. 4 zones and 6 subzones of the known trigonioidaceans are tentatively presented.
\end{abstract}

Guo Fuxiang, Yunnan Institute of Geological Sciences, Baita Road, Kunming, Yunnan, China, February 3rd, 1984.

The Asian non-marine Cretaceous is extensively distributed in China, Japan, Korea, Laos, Thailand, Singapore, Mongolia and the Asian part of the Soviet Union. It exhibits remarkable provincial characteristics that have allowed renewed investigation on the basis of the endemic trigonioidacean faunae. The sequence consists mainly of a suite of non-marine clastic rocks reaching the considerable thickness of $2.000-12.000 \mathrm{~m}$ and containing abundant volcanics in the peri-Pacific areas. It is generally difficult to determine the precise age of any particular formation within the Asian non-marine Cretaceous in terms of the international scale, owing to scarcity of true marine intercalary beds. In order to correlate with marine series, it is necessary first to study its present stratigraphic status.

I would like to express my sincere gratitude to Professor Hao Yichun of Beijing Graduate School, Wuhan College of Geology, for her kindly reviewing the manuscript of this paper.

\section{Subdivision of the Asian non-marine Cretaceous provinces}

On the basis of lithological characteristics controlled by palaeoclimatic factors, the Asian nonmarine Cretaceous may be tentatively divided into two provinces, a southern and a northern, by the line running from the south part of the Ural
Mountains via Tianshan-Qilianshan to Qinling Mountains (Text-figure 1). There is some transitional development locally near the provincial boundary.

\section{The Southern Province}

In this province the non-marine Cretaceous System is dominated by clastic red salt-bearing rocks. The sequence of West Yunnan, which shows general features of the province, may be summarized as follows, in descending order:

Overlying strata: Paleocene: Mengyejing Formation. Brick-red sandstones, siltstones and mudstones intercalated with mud-conglomerates bearing gypsum-salts.

\section{Conformity or Disconformity}

Upper Cretaceous:

Mankuanhe Formation. Purplish red with more or less variegated mudstones and siltstones, saltbearing, yielding ostracods: Cypridea (Cypridea) cavernosa Galeeva, Cypridea (Cypridea) zhengdongensis Ye et Chao, Talicypridea shixuangbannaensis (Ye), Cypris (Cristocypris) zhengdongensis (Ye), Sinocypris jinghongensis Gou, Sinocypris zhengdongensis Gou, Ziziphocypris simokovi (Mandelstam); charophytes: Porochara 


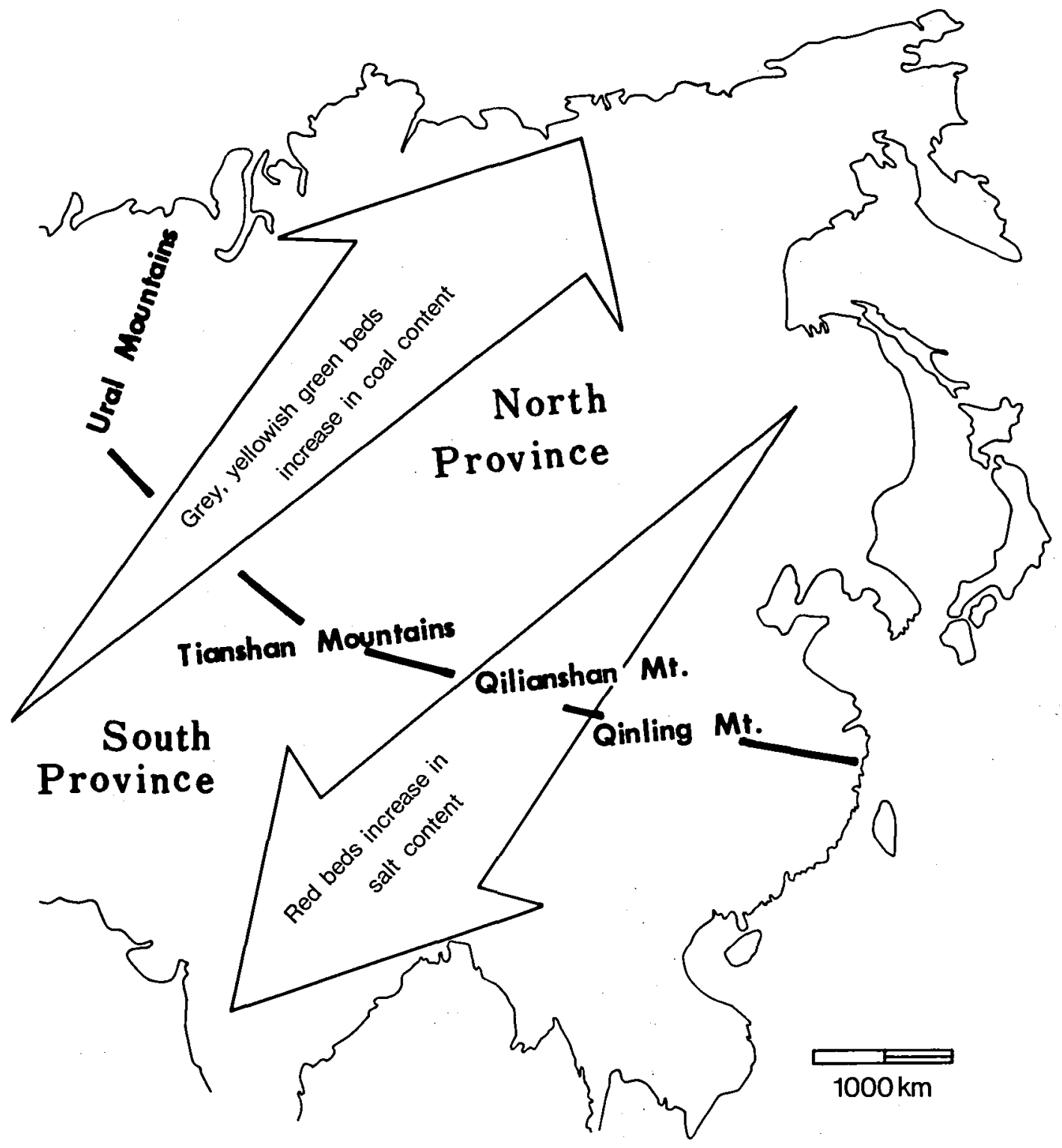

Text-figure 1 DIVISION OF THE ASIAN NON-MARINE CRETACEOUS PROVINCES 
anluensis Z. Wang, Porochara spherica Z. Wang, Porochara oblonga Z. Wang, Huang et S. Wang, Peckichara dangyangensis Z. Wang, Charites tenuisa $\mathrm{Z}$. Wang, etc.

$$
1,000-2,000 \mathrm{~m}
$$

\section{Disconformity?}

Middle Cretaceous:

Bashahe Formation. Grey, greyish green sandstones

$50-200 \mathrm{~m}$

\section{Conformity}

Mangang Formation. Purplish red sandstones, containing bivalves: Trigonioides sinensis $\mathrm{Gu}$ et Ma, Nippononaia (Nippononaia) carinata Kobayashi; ostracods: Monosulcocypris mirabilis Hou, Ye et Cao, Monosulcocypris yunnanensis Hou, Ye et Cao, Cypridea (Cypridea) subquadrata Cao et Yang, Cypridea (Pseudocypridina) ovata Cao et Yang; charophytes: Atopochara trivolvis Peck, etc.

$$
500-3,000 \mathrm{~m}
$$

\section{Conformity}

\section{Lower Cretaceous:}

\section{Jingxing Formation}

Upper Member. Purplish red mudstones and siltstones, with bivalves: Koreanaia yunnanensis Guo, Nippononaia (Eonippononaia) diana Guo, Sinonaia chuxiongensis ( $\mathrm{Gu}$ et $\mathrm{Ma}$ ), Plicatounio (Plicatounio) rostratus Guo et Zhang, Peregrinoconcha nuanliensis Guo; ostracods: Damonella ovata Gou, Jingguella extensa Gou, Darwinula paracrassa Ye, etc.

100-1,300 m

Lower Member. Greyish green, purple sandstones intercalated with purplish red mudstones and siltstones, yielding bivalves: Nippononaia (Eonippononaia) diana Guo, Cyotrigonioides sp., etc.

$$
200-1,400 \mathrm{~m}
$$

\section{Conformity or Disconformity}

Underlying strata: Upper Jurassic Bazhulu Formation. Purplish red, greyish purple sandstones and siltstones.
The Napai and Bali Formation of Guangxi, China, and the corresponding horizon of the Khorat Group of Laos, which are equivalent to the upper Mangang Formation, contain bivalves: Hoffetrigonia (Hoffetrigonia) trigona (Hoffet), Hoffetrigonia (Hoffetrigonia) laotiae (Hoffet), Diversitrigonioides diversicostatus (Hoffet), etc. In Fergana basin of the Soviet Union the horizon equivalent to the Mankuanhe Formation yields bivalves: Pseudohyria (Pseudohyria) aralica (Martinson), Plicatotrigonioides simakovi (Martinson), Plicatotrigonioides kuramensis Martinson, Neotrigonioides gigantus (Martinson), etc.

\section{The Northern Province}

The non-marine Cretaceous System of this province is marked by clastic grey, yellowish green and black formations, bearing coal-kukersit, locally, with more or less purplish red beds. The Cretaceous sequences of West LiaoningNorth Hebei and the Songliao basin show some general features of this province. In West Liaoning and North Hebei there are the following rock formations of Rehe Group in descending order.

Overlying strata: Middle Cretaceous. Sunjiawan Formation. Purplish red, greyish white, greyish green conglomeratic sandstones intercalated with mudstones, yielding bivalves: Nippononaia (Nippononaia) cf. yanjiensis $\mathrm{Gu}$.

\section{Unconformity}

Lower Cretaceous Rehe Group:

Fuxin Formation. Grey, greyish black coal-bearing sandstones and mudstones, with bivalves: Nippononaia (Eonippononaia) sinensis Nie, ?Ferganoconcha subcentris Chernyshev; ostracods: Cypridea vitimensis Mandelstam; plants: Ruffordia goepperti (Dunker) Seward, Onychiopsis elongata (Eeer) Vassilevskaja. $500-1,400 \mathrm{~m}$

\section{Conformity}

Jiufotang Formation. Greyish green, yellowish green sandstones and mudstones intercalated with kukersit, yielding bivalves: Nippononaia (Eonippononaia) sinensis Nie, Nakamuranaia 
chingshanensis (Grabau), Nakamuranaia elongata Gu et Ma, ?Ferganoconcha sibirica Chernyshev, Myrene (Mesocorbicula) tetoriensis (Kobayashi et Suzuki), Sphaerium jeholensis (Grabau); ostracods: Cypridea sinensis Hou; conchostracans: Eosestheria middendorfii (Jones), Diestheria yangliutunensis Chen; insects: Ephemeropsis trisetalis Eichward; fishes: Lycoptera davidi (Sauvage), Lycoptera tokunagai Saito; reptiles: Psittacosaurus chaoyangi Chao et Cheng.

$400-2,000 \mathrm{~m}$

\section{Disconformity}

Jianchang Formation. Greyish purple, greyish green andesites intercalated with agglomerates and volcanic breccias.

$3,500 \mathrm{~m}$

\section{Disconformity}

Jingangshan Formation. Tuffaceous grey, greyish green, greyish white mudstones and sandstones, with bivalves: Nakamuranaia chingshanensis (Grabau), ?Ferganoconcha triangularis (Ragozin), Sphaerium jeholensis (Grabau); ostracods: Cypridea sulcata Mandelstam, Lycopterocypris infantilis Lubimova; conchostracans: Eosestheria middendorfii (Jones), Eosestheria jingangshanensis Chen; insects: Ephemeropsis trisetalis Eichwald; fishes: Lycoptera muroii (Takai).

$$
400-2,000 \mathrm{~m}
$$

\section{Disconformity}

Yixian Formation. Greyish purple andesites, greyish black basalts, intercalated with agglomerates and tuffaceous sandstones and mudstones, containing conchostracans: Nestoria aff. prissovi Krasinetz; insects: Ephemeropsis trisetalis Eichwald.

$2,500 \mathrm{~m}$

\section{Unconformity}

Underlying strata: Upper Jurassic. Tuchengzi Formation. Greyish purple andesites.

In Songliao basin, where the Cretaceous is well developed, there is the following sequence, which shows general features of the Middle and
Upper Cretaceous, summarized as follows, in descending order.

Overlying strata: Eocene. Yian Formation. Fine-grained greyish white sandstones.

\section{Unconformity}

\section{Upper Cretaceous:}

Mingshui Formation. Greyish green sandstones and black mudstones, becoming brownish red towards the top, intercalated with conglomerates, containing bivalves: Pseudohyria (Pseudohyria) aralica (Martinson), Protelliptio (Plesielliptio) songhuaensis $\mathrm{Gu}$ et $\mathrm{Yu}$, also ostracods: Cypridea tera Su, etc.

$300-600 \mathrm{~m}$

\section{Conformity}

Sifangtai Formation. Brownish red mudstones intercalated with grey, greyish green, light greyish yellow, greyish white mudstones and sandstones, with bivalves: Pseudohyria (Pseudohyria) obliqua Gu et Ma, Pseudohyria (Pseudohyria) songhuaensis Gu et Yu, Protelliptio (Plesielliptio) songhuaensis $\mathrm{Gu}$ et $\mathrm{Yu}$; ostracods: Talicypridea amoena (Liu); conchostracans: Daxingestheris distincta (Chang et Chen).

$200-400 \mathrm{~m}$

\section{Disconformity or Unconformity}

Nenjiang Formation. Black, greyish green mudstones intercalated with kukersit, yielding bivalves: Pseudohyria sp., Plicatounio (Plicatounio) latiplicatus Gu et Yu; ostracods: Cypridea gunsulinesis Su; conchostracans: Mesolimnadiopsis anguangensis Chang et Chen.

$500-1,000 \mathrm{~m}$

Part of the Nenjiang Formation probably belongs to the Middle Cretaceous.

\section{Conformity}

\section{Middle Cretaceous:}

Yaojia Formation. Brownish red mudstones intercalated with greyish green, greyish black mudstones, containing bivalves: Plicatounio (Plicatounio) latiplicatus $\mathrm{Gu}$ et $\mathrm{Yu}$; ostracods: Cypridea favosa Ye, Ziziphocypris coneta Cea; 


\begin{tabular}{|c|c|c|c|c|c|}
\hline \multirow{3}{*}{ 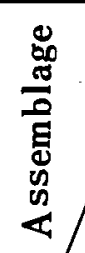 } & \multicolumn{3}{|c|}{ Ornamentation } & \multicolumn{2}{|c|}{ Hinge teeth } \\
\hline & \multirow{3}{*}{\begin{tabular}{|c} 
Radial \\
Radial ribs or \\
also with \\
postero-dorsal \\
oblique ribs
\end{tabular}} & \multicolumn{2}{|c|}{$V$ - shape ribs } & \multirow{2}{*}{$\begin{array}{l}\text { Crenulations } \\
\text { on sides }\end{array}$} & \multirow{2}{*}{$\begin{array}{c}\text { Subumbonal } \\
\text { teeth }\end{array}$} \\
\hline & & Angles & Model & & \\
\hline & & \multicolumn{2}{|c|}{ Absent } & Strong & Absent \\
\hline$\frac{0}{\frac{0}{7}}$ & Multiplicatus & $\begin{array}{c}\text { Small } \\
7^{\circ}-27^{\circ}\end{array}$ & Para- & $\begin{array}{c}\text { Universalized } \\
\text { basically }\end{array}$ & Present \\
\hline 告 & Rariplicatus & $\begin{array}{c}\text { Large } \\
30^{\circ}-130^{\circ}\end{array}$ & $\mathrm{Eu}-$ & $\begin{array}{c}\text { Absent in } \\
\text { majority }\end{array}$ & Absent \\
\hline
\end{tabular}

Table 1. Major morphological characteristics of the three trigonioidacean assemblages.

conchostracans: Dictyestheria elongata Zhang et Chen.

$$
70-200 \mathrm{~m}
$$

\section{Conformity or Disconformity}

Qingshankou Formation. Black, greyish green mudstones and siltstones intercalated with kukersit, yielding bivalves: Nippononaia (Nippononaia) jilinensis Gu et Yu, Plicatounio (Plicatounio) subrhombicus $\mathrm{Gu}$ et $\mathrm{Yu}$, Plicatounio (Plicatounio) equiplicatus $\mathrm{Gu}$ et $\mathrm{Yu}$; ostracods: Cypridea dekhoinensis Sou; conchostracans: Nemestheria qingshankouensis Chang et Chen.

\section{Conformity}

Quantou Formation. Purplish grey, greyish white, greyish green sandstones and dark purple, brownish red mudstones in alternation, intercalated with greyish black mudstones, containing bivalves: Nippononaia (Nippononaia) jilinensis $\mathrm{Gu}$ et Yu; ostracods: Cypridea vetusta Ye.

$500-1,500 \mathrm{~m}$

\section{Conformity or Disconformity}

Underlying strata: Lower Cretaceous. Denglouku Formation. Dark brownish red, greyish green, greyish black mudstones and greyish green, greyish white siltstones, sandstones and conglomerates.

Comparison of the two provinces reveals generally changing trends of rock character: (1) red salt-bearing beds increase from the north to the south, and (2) grey, yellowish green beds containing coal-kukersit increase from the south to the north. Thus, coal measures, for example, occur in Lena coal basin of the Soviet Union, whereas saline formations, for instance, occur in the southeast Asia and Yunnan of China, these locations being close to the south and north ends of the two provinces. 


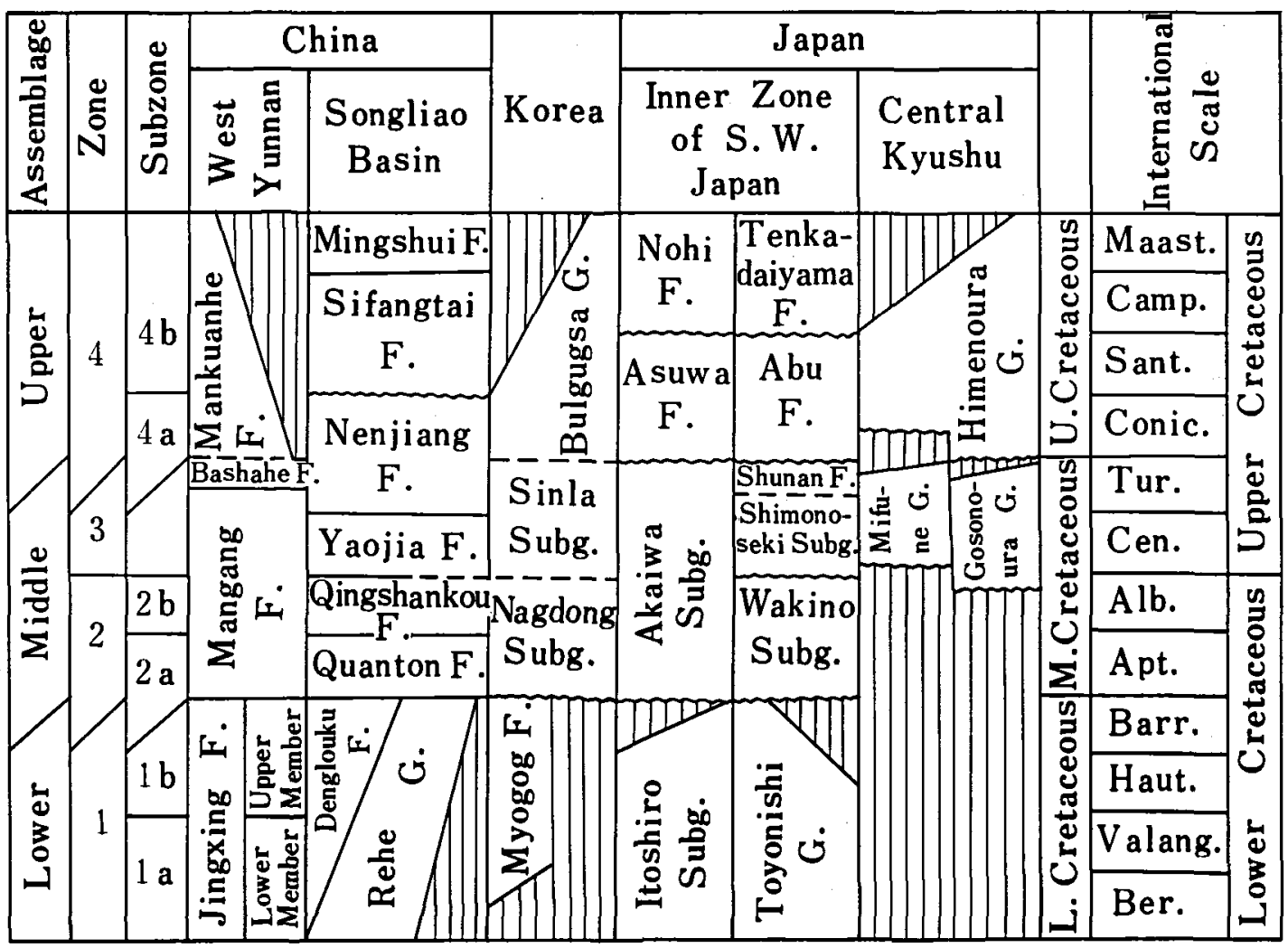

Table 2. Tentative zonation of the Asian non-marine Cretaceous on the basis of trigonioidaceans.

Three major divisions and trigonioidacean zonation of the Asian Cretaceous

The Asian non-marine Cretaceous System contains bivalves, gastropods, ostracodes, conchostracans, insects, fishes, reptiles, charophytes, plants, sporo-pollens, etc., among which trigonioidacean bivalves appear to be of exceptional importance for the subdivision of the succession. The trigonioidaceans exhibit relatively swift evolution together with variation of conspicuous morphological characteristics, making their appearance in the Early Cretaceous, reaching a climax in the Middle Cretaceous, and declining in the Late Cretaceous. They become extinct before the Paleocene. Although the trigonioidaceans are fewer in number than microfossils, they may be used to define several distinct limits by means of their obvious morphological characteristics, and thus they play a significant role in the classifica- tion of the Asian non-marine Cretaceous System.

On the basis of the three evolutionary stages and the morphological features of every phylogenetic stage of these bivalves (Table 1) (Guo, 1981), the trigonioidaceans can be arranged in three assemblages as follows, in ascending order:

A lower, also named $K E P$ or primitive $T N P$ assemblage, characterized by Koreanaia-Eonippononaia-rariplicatus Plicatounio-Sinonaia-Peregrinoconcha;

A middle, known as TNP assemblage, characterized by Trigonioides-Nippononaia s.s. - multiplicatus Plicatounio-Wakinoa-Hoffetrigonia s.s. Kumamotoa;

An upper, designated $P P$ assemblage, represented by Pseudohyria s.s. - PlicatotrigonioidesNeotrigonioides.

The Asian non-marine Cretaceous may be subdivided by the three assemblages into Lower, Middle and Upper Cretaceous, the three provincial series revealing this tripartite character 
(Guo, 1982) (Table 2). The ages of volcanic rocks, determined by radiometric isotopic dating, are respectively $105-108$ m.y. and 85-88 m.y. between the three provincial series ( $\mathrm{Hu}$ et al., 1982).

Naming of the three provincial series awaits further discussion, as does also the selection of stratotypes in cooperation with colleagues when certain conditions mature.

Furthermore, on the basis of the sequence of occurrence of their species. their morphological characteristics and phylogeny, 4 zones and 6 subzones of trigonioidaceans can tentatively be distinguished as follows, in ascending order:

Zone 1: Zone of Koreanaia cheongi Yang Peregrinoconcha nuanliensis Guo - Koreanaia antiqua ( $\mathrm{Gu}$ et $\mathrm{Ma})$, may be divided into two subzones.

Subzone 1a: Subzone of Koreanaia antiqua ( $\mathrm{Gu}$ et $\mathrm{Ma}$ ), represented by the Gaofengsi Formation of Central Yunnan, China.

Subzone 1b: Subzone of Koreanaia cheongi Yang - Nippononaia (Eonippononaia) tetoriensis Maeda - Sinonaia chuxiongensis (Gu et Ma) Peregrinoconcha nuanliensis Guo, can be found in the Itoshiro Subgroup of Japan, the Myogog Formation of Korea, the Puchange Formation and the upper member of the Jingxing Formation of Yunnan, China, and elsewhere.

The age of the Itoshiro Subgroup containing Nippononaia (Eonippononaia) tetoriensis Maeda, an important representative of zone 1 , is thought to be Neocomian (Kimura, 1975; Guo, 1982).

Zone 2: Zone of Trigonioides kodairai Kobayashi and Suzuki - Wakinoa wakinoensis (Ohta) - Nippononaia (Nippononaia) ryosekiana Suzuki, could be subdivided into two subzones in some localities.

Subzone 2a: Subzone of Wakinoa wakinoensis (Ohta) - Nippononaia (Nippononaia) ryosekiana Suzuki, represented by the Lower Wakino Subgrup of Japan and the Lower Nagdong Subgroup of Korea.

Subzone 2b: Subzone of Trigonioides kodairai Kobayashi and Suzuki - Trigonioides sinensis Gu et $\mathrm{Ma}$ - Trigonioides tetoriensis Maeda, represented by the Upper Wakino Subgroup and the Akaiwa Subgroup of Japan, the Middle Upper Nagdong of Korea, the Middle Mangang Formation from Yunnan and the Guantou Formation from Zhejiang, China, the Kokhyar Formation (Кокъярская свита) of Fergana, U.S.S.R.

Nippononaia (Nippononaia) ryosekiana Suzu$\mathrm{ki}$, one of the important representatives of zone 2 , is confined to the Aptian-Albian age according to ammonites and other marine fossils occurring in marine beds of the underlying and overlying strata (Hayami et Ichikawa, 1965; Matsukawa, 1977).

Zone 3: Zone of Hoffetrigonia (Kumamotoa) mifunensis (Tamura) - Hoffetrigonia (Kumamotoa) paucisulcata (Suzuki) - Hoffetrigonia (Hoffetrigonia) kobayashii (Hoffet), represented by the Goshonoura and Mifune Groups of Japan, the Sinla Subgroup of Korea, the Upper Matoushan Formation from Central Yunnan and the Bali Formation from Guangxi, China, and so on.

According to marine fossils occurring in marine intercalations, the Goshonoura and Mifune Groups, containing important representatives of zone 3, Hoffetrigonia (Kumamotoa) matsumotoi (Kobayashi et Suzuki), Hoffetrigonia (Kumamotoa) mifunensis (Tamura), have been thought to be Cenomanian-Turonian, Cenomanian or Upper Albian-Turonian by Matsumoto (1938, p. 24-27; 1977 , p. 68,69$)$, Ohta $(1975$, p. 86,95$)$, Tamura $(1975$, p. $55 ; 1979 ; 1980$, p. $225-235)$ and others.

Zone 4: Zone of Pseudohyria (Pseudohyria) gobiensis MacNeil - Pseudohyria (Pseudohyria) songhuaensis $\mathrm{Gu}$ et $\mathrm{Yu}$ - Plicatotrigonioides kuramensis Martinson, represented by the Nenjiang Formation, the Sifangtai Formation, the Wangsi Group, the Erlian Formation from China, and the Tokubay Formation (Токубайская свита), the Yalovatchy Formation (Яловачская свита) of Fergana, U.S.S.R. Zone 4 could be divided into two subzones in part of the region.

Subzone 4a: Subzone of Pseudohyria (Pseudohyria) gobiensis MacNeil, represented by the Erlian Formation of Inner Mongolia and the Nenjiang Formation of Heilongjiang, China.

Subzone 4b: Subzone of Pseudohyria (Pseudohyria) songhuaensis $\mathrm{Gu}$ et $\mathrm{Yu}$, Sifangtai Formation of Heilongjiang, China.

According to Martinson (1965), some important faunal elements of zone 4, such as Plicatotrigonioides kuramensis Martinson, Neotrigonioides gigantus Martinson, etc., belong to late Turonian-Santonian. 


\section{Dansk sammendrag}

Kridtsystemet i Asien er hovedsagelig ikke-marint. Det kan deles $i$ to provinser: en nordlig, domineret af kulførende, klastiske grå-gullige formationer, og en sydlig, domineret af saltførende, klastiske røde facies.

Trigonioidacea (muslinger) i marine indslag bruges til at dele sekvensen i nedre, mellem og øvre kridt; fire zoner og seks underzoner er foreslået.

\section{References}

Anatoleva, A. I., 1978: Evolution of basic limits of red formations. Inst. Geol. Geophys., Siberia Branch, Acad. Sci. USSR, Papers, no. 46, p. 1-189. (in Russian).

Grabau, A. W., 1923: Cretaceous fossils from Shantung. Bull. Geol. Surv. China, 5,2, p. 143-181.

Gu Zhiwei, 1962: The Jurassic and Cretaceous Systems of China. Scientific Reports of Stratigraphic Conference of China. p. 1-84. Science Press, Beijing. (in Chinese).

Gu Zhiwei, 1980: Studies on the Jurassic and Cretaceous Systems of Zhejiang, China. Classification and correlation of Mesozoic volcanic sedimentory rocks of Zhejiang-Anhui, China. p. 2-68. Science Press, Beijing. (in Chinese).

Guo Fuxiang, 1981: Bivalve fauna of the Jingxing Formation from West Yunnan and on the origin of the Asian Cretaceous trigonioidaceans. Selected Papers, 12th Ann. Symposium, Palaeont. Soc. China. p. 61-79, pls. 1-3. Science Press, Beijing. (in Chinese).

Guo Fuxiang, 1982: Tripartite character and trigonioidacean zonation of the Asian non-marine Cretaceous System. Acta Geol. Sinica, 56,4, p. 324-333, pls. 1, 2. (in Chinese).

Hao Yichun et al., 1982: Stratigraphical division of non-marine Cretaceous and the Juro-Cretaceous boundary in China. Acta Geol. Sinica, 56,3, p. 187-199. (in Chinese).

Hase, A., 1960: The late Mesozoic formations and their molluscan fossils in West Chugoku and North Kyushu. Jour. Sci., Hiroshima Univ., C, 3,2, p. 281-342, pls. 31-39.

Hayami, I. et Ichikawa, T., 1965: Occurrence of Nippononaia ryosekiana from the Sanchu Area, Japan. Trans. Proc. Palaeont. Soc. Japan, N. S., 60, p. 145-155, pl. 17.

Hoffet, J. H., 1937: Les lamellibranches saumatres du Senonien de Muong Phalane (Bas-Laos). Bull. Serv. geol. d'Indochine, 24,2 , p. $4-25$, pls. 1-5.

Hu Huagan et al., 1982: On the ages of Jurassic and Cretaceous volcanic rocks by radiometric dating. Acta Geol. Sinica, 56,4 , p. $315-323$. (in Chinese).

Kimura, T., 1975: Middle-late early Cretaceous plants newly found from the upper course of the Kuzuryu river area, Fukui Prefecture, Japan. Trans. Proc. Palaeont. Soc. Japan, N. S., 98, p. 55-93, pls. 5-8.

Kobayashi, T., 1968: The Cretaceous non-marine pelecypods from the Nam Phung Dam site in the northern part of the Khorat Plateau, Thailand with a note on the Trigonioididae. Geol. Palaeont. SE Asia, 4, p. 109-138, pls. 20-23.
Kobayashi, T. and Suzuki, K., 1936: Non-mairine shells of the Naktong-Wakino Series. Japan. Jour. Geol. Geogr., 13,34 , p. 243-257, pls. $27-29$.

Maeda, S., 1962: On the occurrence of Nippononaia in the late Mesozoic Tetori Group. Trans. Proc. Palaeont. Soc. Japan, N. S., 46, p. 243-248, pl. 38.

Maeda, S., 1963: Trigonioides from the late Mesozoic Tetori Group, Central Japan. Ibid., 51, p. 79-85, pl. 12.

Martinson, G. G., 1961: Mesozoic and Cainozoic mollusca of continental deposits from Siberia Platform, Zabaykalia and Mongolia. Papers Bayk. Limn. Station, Siberia Branch, Acad. Sci. USSR, 19, p. 1-332, pls. 1-26. (in Russian).

Martinson, G. G., 1965: Biostratigraphy and continental fauna of the Cretaceous of Fergana. Pt. Monog. Collec. Acad. Sci. USSR, p. 101-152, pls. 1-11. (in Russian).

Martinson, G. G., 1982: Late Cretaceous mollusca of Mongolia. Palaeont. Inst. Acad. Sci. USSR, Papers, 17, p. 1-81, pls. 1-16. (in Russian).

Martinson, G. G. et al., 1982: Mesozoic lake basins of Mongolia. Inst. Lake-management, Acad. Sci. USSR, Nauka, Leningrad, p. 1-211. (in Russian).

Matsukawa, M., 1977: Cretaceous System in the eastern part of the Sanchu "Graben", Kwanto, Japan. Jour. Geol. Soc. Japan, 83,2, p. 115-126, pls. 1,2. (in Japanese).

Matsumoto, T., 1938: Geology of the Goshonoura Island, Amakusa, with special reference to the Cretaceous stratigraphy. Ibid., 45, p. 1-46, pls. 1, 2. (in Japanese, with palaeontological description in English).

Matsumoto, T., 1977: Zonal correlation of the Upper Cretaceous in Japan. Palaeont. Soc. Japan, Spec. Pap. 21, p. 63-74.

Morris, F. K., 1936: Central Asia in Cretaceous Time. Bull. Geol. America, 47, p. 1477-1534, pl. 2.

Nanjing Institute of Geology and Palaeontology, Academia Sinica, 1975: Mesozoic red beds of Yunnan. Science Press, Beijing. p. 1-201. (in Chinese).

Ohta, Y., 1960: The zonal distribution of the non-marine fauna in the Upper Mesozoic Wakino Subgroup. Mem. Fec. Sci. Kyushu Univ., Ser. D, Geol., 9,3.

Ohta, Y., 1975: Notes on the genus Trigonioides (Bivalvia). Bull. Fukuoka Univ. Educ., 24,3, p. 79-98. (in Japanese).

Tamura, M., 1975: New occurrence of Trigonioides (Kumamotoa) mifunensis Tamura and a note on Pterotrigonia sakakurai (Yehara) from Goshonoura Island, Kumamoto Prefecture, Japan. Mem. Fac. Educ., Kumamoto Univ., 24, Sec. 1, p. 53-58, pls. 1, 2.

Tamura, M., 1980: A summary of the Cretaceous bivalves of fresh and brackish water in Japan. Jour. Geol. Soc. Korea, 16,4 , p. $223-238$.

Yang, S. Y., 1976: On the non-marine molluscan fauna from the Upper Mesozoic Myogog Formation Korea. Trans. Proc. Palaeont. Soc. Japan, N. S., 102, p. 317-333, pls. 33, 34.

Yang, S. Y., 1979: Some new bivalve species from the Lower Gyeongsang Group, Korea. Ibid., 116, p. 223-234, pls. 27, 28. 